\title{
ETNOGRAFSKA ZBIRKA O PRIMORSKIM BUNJEVCIMA U GRADSKOME MUZEJU SENJ
}

\author{
Blaženka LJUBOVIĆ \\ Gradski muzej Senj \\ Milana Ogrizovića 5, 53270 SENJ
}

\section{UVOD}

$\mathrm{P}$ rilogom će biti predstavljena Etnografska zbirka primorskih Bunjevaca, nastanjenih na području Grada Senja i šire okolice, koja od početaka rada Muzeja čini dio fundusa Gradskog muzeja Senj. Radom se čitatelje želi upoznati s poviješću nastanka Zbirke, od prikupljanja materijala i podataka, do konačne obrade Fundusa i postava u Muzeju.

Zbirka obuhvaća nekoliko cjelina: bunjevačke migracije, tradicijski način života, stanovanje, prehrana, odijevanje, obrti, poljodjelstvo i dr., koje se sadržajem međusobno nadopunjuju te predstavljaju dio bogate tradicijske kulture primorskih Bunjevaca.

Predstavljeno je i postavljanje Zbirke kao gostujuće izložbe u Subotici, u srpnju 2007. godine. Subotica je bila mjesto gostovanja Izložbe, kao prostor na kojem žive podunavski Bunjevci, bački Hrvati.

Prostornim određenjem možemo razlikovati tri bunjevačke seobe (Šarić 2008: 35), a početkom 17. stoljeća $^{1}$ senjsku okolicu naseljava jedna bunjevačka grana.

Izložbom smo se usredotočili na etnografske predmete koji se odnose na jedan dio područja koje danas nastanjuju primorski Bunjevci (planinski prostor Velike Kapele i Velebita) te mahom na razdoblje od polovice 19. stoljeća do polovice 20. stoljeća. Živeći na tom području ljudi su stvarali materijalnu i duhovnu kulturu koju danas u Muzeju poimamao kao značajno tradicijsko i kulturno naslijeđe, vrijedno muzejske prezervacije i prezentacije. Godinama sakupljani etnografski predmeti iz okolice Grada Senja, usustavljeni su u Etnografsku zbirku koja danas čini važan dio fundusa Gradskog muzeja Senj. ${ }^{2}$

\section{OSNUTAK ETNOGRAFSKE ZBIRKE ${ }^{3}$}

radski muzej Senj kompleksna je kulturna institucija čija etnografska zbirka Bunjevaca u cilju struč-

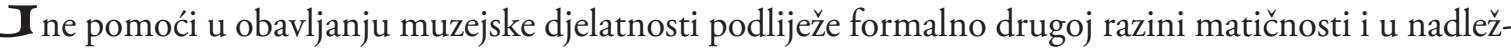
nosti je Etnografskog muzeja Istre u Pazinu, koji podliježe prvoj razini, odnosno Etnografskom muzeju u Zagrebu. ${ }^{4}$

Muzej u Senju osnovan je 1962. godine. Sakupljanje etnografske građe počinje od osnutka Gradskog muzeja, a aktivnije i sustavnije od 1965. godine, otkupom građe na terenu. Ante Glavičić, dugogodišnji kustos i ravnatelj Gradskoga muzeja (od 1960. do 1997. godine), sakupljajući etnografsku građu na senjskome području rekao je: "Želio sam ispuniti obećanje dato cijenjenim suradnicima profesorima Marijani

1 O seobama vidi više u: Karoly 1890:243-251; Pavelić 1991., Pavličević 1985:281-309, 1989:147-172; Šarić 2008:35 i Bogović 2008:69.

2 Uz tu zbirku, u Gradskom muzeju Senj smještene su: Arheološka i hidroarheološka zbirka, Zbirka glagoljice, Prirodoslovna zbirka te tri stalne izložbe: Senj i Senjani u Domovinskom ratu, Intelektualni krug i Senjsko pomorstvo kroz povijest.

3 Arhivska građa Gradskog muzeja Senj, od 1962. do 1984. godine.

4 Više: www.mdc.hr 
i Branimiru Gušiću da ću raditi na sakupljanju etnografske grade Bunjevaca i osnutku zbirke. Iako nisam etnolog, etno-baština mi je vrlo bliska i pri srcu te sam kako sam znao i umio, iz ljubavi prema toj gradi, uložio sav svoj trud $i$ znanje u cilju spašavanja i sakupljanja te grade."s

Zahvaljujući A. Glavičiću od šezdesetih su godina nadalje, sačuvani i pohranjeni mnogobrojni etnografski predmeti koji su se dotad nalazili u posjedu malobrojnih, stalno naseljenih stanovnika u rasutim naseljima smještenim u senjskomu zaleđu.

U više je navrata, sedamdesetih i osamdesetih godina 20. stoljeća, Muzej u okviru svojih redovitih djelatnosti organizirao prikupljanje etnografskih predmeta, koje je Glavičić nazivao etno-akcijom. Bio je to svojevrsni poziv za pomoć brojnim suradnicima iz struke, pojedinim tadašnjim muzejima i Zavodima za kulturu. ${ }^{6}$ Akcija je provođena osamdesetih godina 20. stoljeća, a radilo se na temeljitoj evidenciji i otkupu građe na području ondašnje Općine Senj. Akcija je imala za cilj prikupiti građu, što je trebalo doprinijeti rekonstrukciji i dopuni Etnografske zbirke, a obuhvatila je šire područje prikupljanja etnografskih predmeta, lokaliteta i naselja: Krivi Put, Alan, Vratnik, Stolac, Krasno, Sv. Juraj, Lukovo, Klade, Starigrad, Živi Bunari, Jablanac te Prizna-Karaula. Bile su uključene mnoge institucije: Gradski muzej Senj, Republički zavod za zaštitu spomenika kulture i Regionalni zavod za zaštitu spomenika kulture, te brojni stručni suradnici Muzeja, koji su radili na obradi i procjeni prikupljene građe. ${ }^{7}$ Poziv za prikupljanje građe bio je upućen u vrijeme kada je većina predmeta bila već dobrim dijelom napuštena iz svakodnevne uporabe, uslijed industrijalizacije i pojačanih migracija sedamdesetih godina 20. stoljeća.

Stručni tim, na čelu s A. Glavičićem, niz je godina ${ }^{8}$ terenskim obilascima vršio otkupe građe, koja se pohranjivala u Muzej s daljnjim ciljem očuvanja i proučavanja tradicijske kulture i identiteta primorskih Bunjevaca. Sakupljanje je otežavala slaba prometna povezanost između naselja, te nepristupačnost zaselcima i napuštenim ljetnim stanovima.

Glavičić je zabilježio kako su se na terenu suočavali s brojnim problemima spašavanja etnografskih predmeta, bilo radi nesuglasica s vlasnikom oko otkupa, nedovoljnih financijskih sredstava ili zbog činjenice da su naselja već tada bila depopulirana. Nedostajali su ljudi koji bi dali potrebne odgovore i objašnjenja o nazivima i korištenju pojedinih predmeta, o proizvodnji istih na selu, te o načinu uporabe. ${ }^{9}$

Danas Etnografska zbirka sadrži više od 700 predmeta. Za stanovnike okolice Grada, ona ima veliku simboličku vrijednost jer je velik broj predmeta donesen i doniran u Muzej, od strane lokalnog stanovništva. Objektivan značaj Zbirke leži u mogućnostima očuvanja predmeta i uvida u njezin sadržaj radi budućih etnoloških i povijesnih istraživanja tradicijske kulture primorskih Bunjevaca. ${ }^{10}$

5 Citat uzet iz dopisa Gradskog muzeja Senj dr. Jelki Ribarić, direktoru Etnografskog muzeja Hrvatske u Zagrebu, Urbroj: 01-75/72 od 3. studenoga 1972.

6 Ostale muzejske institucije na području Hrvatske rijetko su pratile etnografsko-povijesnu građu Bunjevaca. Iznimku čine Etnografski muzej Hrvatske u Zagrebu i Narodni muzej u Rijeci.

7 Značajnu financijsku pomoć prof. Glavičić imao je od Republičkog zavoda za kulturu SR Hrvatske i SIZ-a za kulturu Općine Senj, a imao je i stručnu podršku: Regionalnog zavoda za zaštitu spomenika kulture iz Rijeke i Zagreba, Hrvatskog etnološkog društva, Etnografskog muzeja iz Zagreba, Etnološkog zavoda JAZU-a, Narodnog muzeja u Rijeci, Muzeja Like Gospić i Povijesnog muzeja Hrvatske u Zagrebu, prof. Branimira i Marijane Gušić, te etnologa Milovana Gavazzija s Filozofskog fakulteta u Zagrebu i Republičkog fonda za unaprijeđivanje kulturne djelatnosti SR Hrvatske, kao i od drugih muzealaca i etnologa koji su se bavili ovim znanstvenim područjem.

8 Od šezdesetih do osamdesetih godina 20. stoljeća. Prikupljanje građe najčešće se organiziralo kroz planirane stručne ekskurzije u kojima su sudjelovali stručni suradnici Gradskog muzeja. Građa je većim dijelom sakupljena putem otkupa, a manjim dijelom donacijama.

9 Korespodencija Gradskog muzeja Senj tj. direktora A. Glavičića s raznim institucijama: Upravnom odboru Republičkog fonda za unapređenje kulturnih djelatnosti, Komisiji za otkup umjetnina i građe spomeničkog značenja Zagreb, Urbroj:29-1969 od 13. ožujka 1969.; Urbroj:11/2-1970 od 13. ožujka 1970.; Urbroj: 01-49/72 od 22. lipnja 1972.; Urbroj:01-73/72 od 15. listopada 1972.; i Urbroj: 01-12/79 od 1. lipnja 1979.

10 U okvirima znanstvenog projekta Identitet i etnogeneza primorskih Bunjevaca koji je bio od 1998. do 2007. godine, a od 2008. godine do danas nastavljen pod nazivom Identitet i etnokulturno oblikovanje Bunjevaca, pod vodstvom dr. 
Predmeti su u okviru Zbirke sakupljani po grupama:

1. Tekstilni predmeti domaće proizvodnje (tkani ili pleteni od vune, konoplje, lana i dlake).

2. Alatke kojima se pripremao materijal za izradu tekstilnih predmeta

3. Predmeti ručne izrade vezani za uzgoj stoke, obradu zemlje (poljodjelstvo) i druge radove.

4. Predmeti vezani za pojedine obrte: kovač, kolar, bačvar, stolar, opančar, postolar, bravar i dr.

5. Predmeti vezani za pomorstvo, ribolov, brodogradnju (primorske padine Velebita)

6. Dijelovi pokućstva, pribor za kućanstvo, predmeti koji su vezani za ognjište, kuhanje, rasvjetu i grijanje, predmeti od drva.

7. Predmeti koji su služili za prijevoz i prijenos tereta, čuvanje hrane, vode te poljoprivrednih proizvoda.

8. Pastirski pribor.

9. Predmeti izrađeni od zemlje (zemljane posude lončara iz Podgorja i Like), posude izrađene od željeza i drugih materijala, odnosno predmeti koje su Bunjevci proizvodili ili kupovali za potrebe svakodnevnog života. ${ }^{11}$

Zbirka se s godinama nadopunjavala i proširivala. U funkciji kustosa i ravnatelja, A. Glavičić prvi je dio sakupljenih predmeta s kratkim opisom, ali bez tematskog grupiranja, upisao u Glavnu knjigu muzejskih predmeta Gradskog muzeja Senj. ${ }^{12}$ Kompletiranje postojeće etnografske zbirke u Muzeju od početka je bilo shvaćeno kao posao od znanstvenog, kulturnog i regionalno-turističkoga značaja, no Zbirka danas, smatrala sam kao ravnateljica i kustosica Muzeja, traži suvremeno sagledavanje. Zbirku treba promatrati i vrednovati u kontekstu aktualnih privrednih tijekova i svijetu koji se ubrzano mijenja. Ona je time poimana kao, kako dinamičan, tako i ciljano statičan dokument nekadašnjeg (građa) i sadašnjeg (postav) vremena, promjenljiva i nepromjenljiva istovremeno.

\section{REKONSTRUKCIJA ETNOGRAFSKE ZBIRKE KAO DIJELA STALNOG POSTAVA}

Toš oš je 1969. godine planirano da se sakupljena etnografsko-povijesna građa usustavi u etnografsku zbirku. Budući da Gradski muzej Senj nikada nije imao zaposlenog etnologa, nije bilo niti sustavnog plana prezentacije etnografske građe. A. Glavičić ipak je imao nadzor nad predmetima koji su u Muzej stizali, a to je ostvarivao pridruživanjem inventarnog broja svakom predmetu. Ipak, 2001. godine ustanovljeno je kako su vremenom, papirići s brojem na pojedinim predmetima izblijedili ili otpali, te se opisu predmeta i broju iz spomenute Glavne knjige predmeta nisu adekvatno i provjereno mogli pridružiti predmeti koje smo zatekli u Zbirci. Stoga je bilo potrebno prije svega izvršiti novu inventarizaciju predmeta, kako već postojećih, tako i u međuvremenu novopridošlih, neinventariziranih predmeta. Također, od svojeg osnutka Gradski muzej Senj nije imao niti izdvojen spremišni prostor, te je cjelokupna građa, bez nužne selekcije u muzejskoj prezentaciji, bila izložena očima posjetitelja. Stari postav nije imao jasnu izložbenu koncepciju i katkad je nalikovao na depo ${ }^{13}$.

sc. Milanom Černelić, izv. prof. s Odsjeka za etnologiju i kulturnu antropologiju Filozofskog fakulteta Sveučilišta u Zagrebu, pronađeno je više predmeta materijalne kulture koji su fotografirani i opisani, ali uz te predmete za istraživanje i interpretaciju koristili su i predmete pohranjene u okviru Etnografske zbirke Gradskog muzeja Senj. Pojedini sudionici i istraživači, ujedno su i autori priloga u I i II. svesku Monografije o Krivome Putu.

11 Kod sakupljenih predmeta bilo je teško odrediti majstore, godinu izrade većine predmeta, funkciju i kvalitetu, a njihovo stanje uz ostale elemente utjecalo je na prodajnu cijenu koja se temeljila na realnoj procjeni vrijednosti.

12 Prof. A. Glavičić je tada bio jedina zaposlena stručna osoba (po struci arheolog i povjesničar).

13 Riječ je o slikovitom i vjerodostojnom opisu autorice ovog priloga koja od 1. srpnja 1997. godine radi kao ravnateljica i viša kustosica Gradskog muzeja Senj. 
Nadolazeće 2005. godine trebala se obilježiti 400. godišnjica doseljenja Bunjevaca na senjsko područje. ${ }^{14}$ Djelatnici Muzeja ${ }^{15}$ željeli su to obilježiti i preuređenjem etnografske zbirke.

Godine 2001. susreli smo se, kao ondašnji djelatnici Muzeja, s dilemom: da li postav osuvremeniti ili zadržati u prezentaciji ideju ranijeg postava: izložiti sve predmete, čak i kada se neki ponavljaju, te time prikazati bogatstvo fundusa (više potpuno istih predmeta) što bi muzeološki bilo opravdano. ${ }^{16}$

Kako Muzej nije imao zaposlenog etnologa, inventarizaciju su od 2001. do 2004. godine obavljale vanjske suradnice, tada netom diplomirane etnologinje (Ivana Šarić Žic iz Ministarstva kulture, Konzervatorskog odjela u Rijeci i Marijeta Rajković) te tadašnje apsolventice etnologije (Tihana Rubić, Marija Brajković, Lidija Dokuzović i Danijela Birt) na Odsjeku za etnologiju i kulturnu antropologiju Filozofskog fakulteta u Zagrebu. ${ }^{17}$ Većina njih bile su i istraživačice-suradnice na znanstvenom projektu Identitet i etnogeneza primorskih Bunjevaca, voditeljice dr.sc. Milane Černelić.

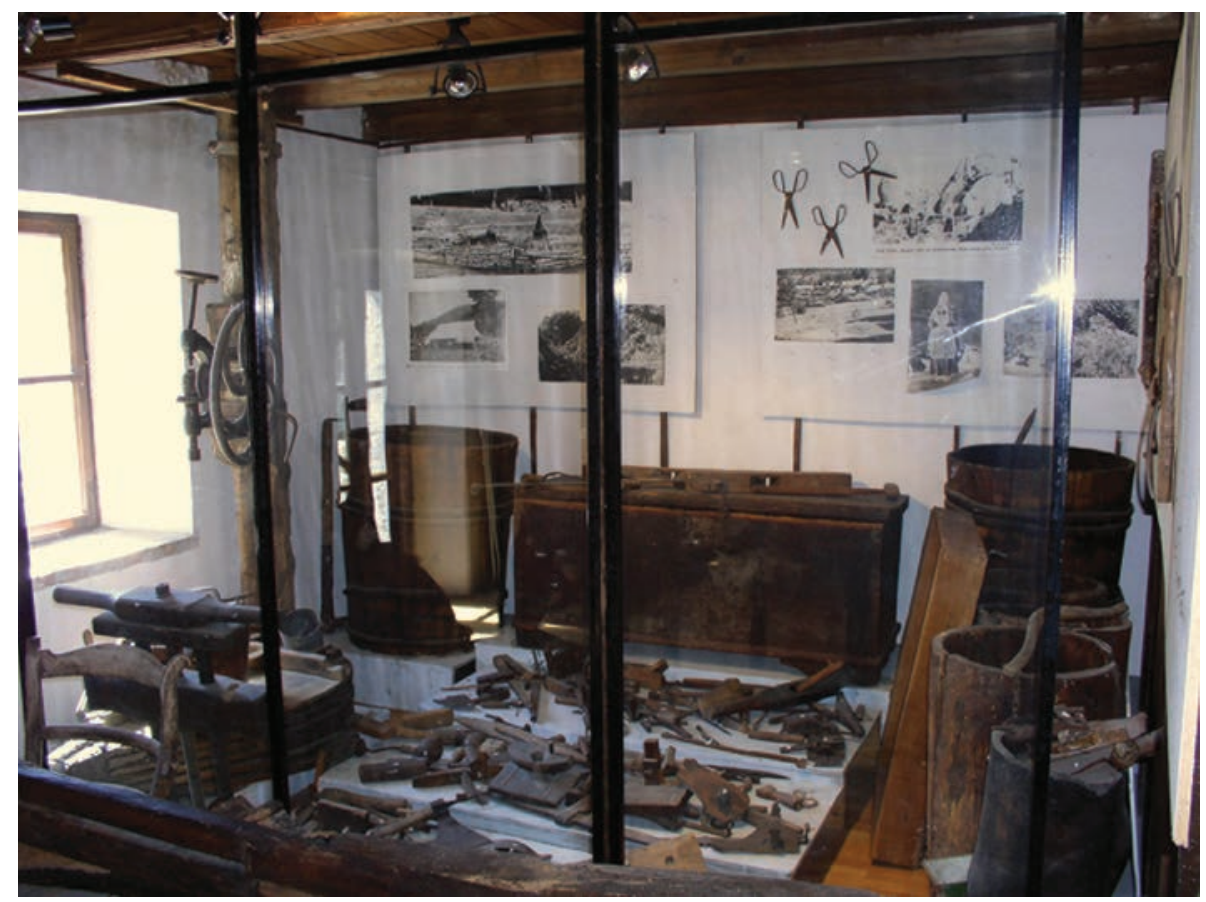

Slika 1: Detalj iz, starog postava etnografske zbirke, GMS; snimio Darko Nekić, listopad 1997.

Naposljetku, opredijelili smo se za promjenu postava za koju je bilo potrebno izvršiti reviziju, selektirati predmete (prema sadržaju, reprezentativnosti, stanju očuvanosti i sl.) te predstaviti Zbirku javnosti.

Cilj nam je bio predstaviti tradicijski život primorskih Bunjevaca korištenjem originalnih predmeta zajedno s arhivskom i fotografskom građom. To smo nastojali kroz muzejsku prezentaciju „bunjevačke priče " postavljene u kontekst prvih seoba, naseljavanja, oblikovanja životnog prostora, načina stanovanja,

14 Tim povodom smo 2005. godinu proglasili godinom Bunjevaca u tijeku koje je u povodu Međunarodnog dana muzeja postavljena prigodna izložba kao uvod u završne pripreme konačnog preuređenja stalnog postava etnografske zbirke kojeg je pratio prigodni deplijan; nadalje znanstveni časopis Senjski zbornik za godinu 2005., također je posvećen toj visokoj obljetnici i u njemu je objavljen i veliki broj radova na temu tradicijske kulture Bunjevaca.

15 U uređenju novog postava sudjelovali su svi djelatnici Gradskog muzeja Senj: Blaženka Ljubović, prof. ravnatelj i viši kustos, Darko Nekić, prof. i viši kustos (danas gradonačelnik Grada Senja), Melanija Prpić, dipl. oec. i tehničko osoblje: Marija Margeta, Branimir Turina i Dragan Žunić.

16 O ovome više vidjeti u: Muzeologija, 38 (2001.), 78-79, o izložbenoj djelatnosti, tipologiji izložbenih postava te o njihovom razvrstavanju u zbirke. Posebno su značajne didaktičke izložbe koje imaju svrhu pružanja informacija, upućivanja i podučavanja budući da ova zbirka predstavlja ukupnost života primorskih Bunjevaca nastanjenih na senjskom području.

17 Odsjek je 2004. godine preimenovan iz Odsjeka za etnologiju u Odsjek za etnologiju i kulturnu antropologiju. 


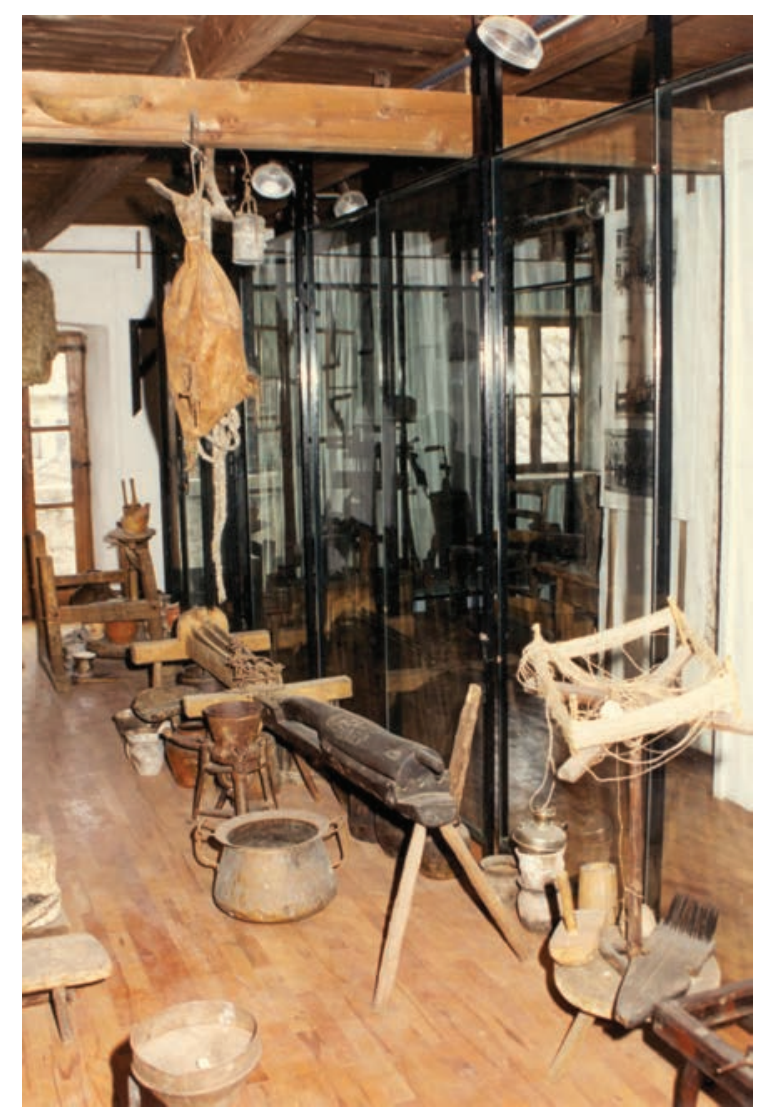

Slika 2: Detalj iz starog postava etnografske zbirke, GMS, snimio Darko Nekí, listopad 1997.

obavljanja kućanskih poslova, tekstilne proizvodnje, snabdjevanja i vodoopskrbe, do šezdesetih i sedamdesetih godina 20. stoljeća.

Tako smo prvotnoj statičnosti predmeta izloženih u tematskim skupinama, na legendama dodali povijesnu priču primorskih Bunjevaca, koja je obilježena migracijama, ratovima, prilagodbama i traženjima novih uvjeta i prostora življenja. Čini nam se da je upravo to dalo znatan pečat bunjevačkoj tradicijskoj kulturi. Izloženi predmeti bili su zamišljeni kao prožimanje povijesnih podataka s pričom o vještinama i tradicijskom načinu življenja primorskih Bunjevaca.

Na uređenju postava i stručnoj obradi etnografske građe, radovi su vođeni od 2000. do 2006. godine. Zbirka je otvorena i predstavljena javnosti 20. travnja 2006. godine u povodu obilježavanja Dana Grada Senja. ${ }^{18}$

18 Od ideje do realizacije novog-starog postava etnografske zbirke-izložbe prošlo je više godina za što je bila potrebna financijska i stručna pomoć bez koje ne bismo ostvarili zacrtani projekt. Zbog toga smo vrlo zahvalni svima koji su nam financijski pomogli i bez čije pomoći ova zbirka ne bi ugledala svjetlo dana: Ministarstvu kulture RH, Ličkosenjskoj županiji, Gradu Senju, a tehničku pomoć pružila nam je Uprava šuma Senj. U stručnom dijelu svesrdnu pomoć pružili su nam: Odsjek za etnologiju i kulturnu antropologiju Filozofskog fakulteta u Zagrebu (dr. sc. Milana Černelić, izv. prof. i suradnici studenti na znanstvenom projektu Identitet i etnogeneza primorskih Bunjevaca, Marijeta Rajković, Tihana Rubić, Danijela Birt, Marija Brajković), te studentice: Lidija Dokuzović, Anita Akšić i Marija Ivatek; Konzervatorski odjel u Rijeci (Ivana Šarić-Žic, prof.,); te Etnografski muzej Istre, koji je matični muzej za ovu Zbirku (mr.sc. Lidija Nikočević i Tanja Kocković). Ostali su brojni vanjski suradnici radili kako na uređenju prostora, tako i stručnoj obradi i zaštiti građe. 


\section{KONCEPCIJA NOVE ETNOGRAFSKE ZBIRKE}

$\mathrm{I}$ zložbeni prostor smješten je na trećem katu zgrade Muzeja, a obuhvaća površinu od cca $200 \mathrm{~m}^{2}$. Prilikom postavljanja izložbe odlučili smo građevinskim zahvatom otvoriti stropni grednik, te na taj način dobiti veći izložbeni prostor (postavljanjem nekih predmeta u potkrovni dio), ali i bolje dočarati interijer drvenih greda bunjevačke tradicijske kuće, preciznije, tavanskog prostora koji je služio za odlaganje uporabnih predmeta i osnovnih namirnica.

U uvodnom dijelu Zbirke izloženi su zemljovidi na kojima su vidljive bunjevačke migracije, dok je u glavnoj izložbenoj dvorani zastupljeno nekoliko tematskih cjelina: prikaz unutrašnjosti bunjevačke kuće, tradicijska prehrana, prikaz obrtničke djelatnosti i ostalih zanata, prikaz poljodjelstva i stočarstva, transport i vodoopskrba, tekstilno rukotvorstvo i replike bunjevčkih nošnji. Svaka od ovih tematskih cjelina u daljnjem je tekstu pojašnjena kako bi se stekao cjelovitiji uvid u koncepciju postava.

\section{1. BUNJEVAČKE MIGRACIJE}

Drema M. Černelić, Bunjevci su hrvatska etnička skupina podijeljena u tri ogranka (Černelić 2003:407-424):

dalmatinski (Dalmatinska zagora i jugozapadni dijelovi Bosne i Hercegovine)

primorsko - lički (Gorski kotar, Hrvatsko primorje i Lika)

podunavski (Bačka, južna Mađarska i okolica Budimpešte)

Znanstvenim proučavanjem povijesnih izvora, te analizom etnoloških i lingvističkih pokazatelja, dokazane su sličnosti u predmetima materijalne i elementima duhovne i društvene kulture ovih triju bunjevačkih grana, iako žive na međusobno udaljenim prostorima.

U povijesnim dokumentima zabilježene su brojne bunjevačke seobe, od kojih su veće bile 1605 . i 1627. godine kada uz pomoć krajiških časnika dolaze u Lič u Gorskom kotaru odakle će se proširiti sve do Senja i naseliti senjsku okolicu. Poslije oslobođenja Like od Osmanlija (1689.) počinju naseljavati i krajeve s druge strane Velebita (Pazarišta, Smiljan, Sv. Rok, Lovinac...) (Pavičić 1962). Seobe bačkih Bunjevaca, koje ljetopisne knjige nazivaju Dalmatincima (Dalmatae) nisu bile istodobne. Iako je seoba u Podunavlje bilo i ranije, najznačajnijim i najbrojnijim se smatraju one iz 17. stoljeća, kada se Bunjevci naseljavaju u krajeve između Dunava i Tise koje i danas nastanjuju. Uz navođenje izvora i relevantne literature, ovaj di Zbirke, dakle, govori o doseljavanju primorskih Bunjevaca na područje Krivoga Puta.

\section{2. GOSPODARSTVO I OBRTNIČKE DJELATNOSTII9}

$\mathrm{O}$ novne gospodarske grane u senjskoj okolici bile su stočarstvo i zemljoradnja, a pojedinci su se bavili i obrtništvom (stolari, kolari i kovači), lovom na divlje životinje, pčelarstvom i kirijanjem (izvlačenjem trupaca iz šume).

Bunjevci u senjskoj okolici uzgajali su: volove, krave, konje, ovce, koze, magarce, mule, svinje i perad (najčešće kokoši). Posjedovali su nekoliko jutara zemlje, ponajviše u obliku oranica i livada koje su obrađivali i kosili. Od poljoprivednih kultura najučestalije žitarice bile su ječam i zob, a u nekim predjelima i pšenica, heljda i kukuruz. Od povrtlarskih kultura sadio se krumpir, kupus (zelje), repa, mahunarke, mrkva i salata. Od voća su se najčešće uzgajale šljive i jabuke.

19 Tekst za legendu koja se odnosi na dio zbirke o gospodarstvu i obrtničkim djelatnostima, napisala je Marijeta Rajković. 


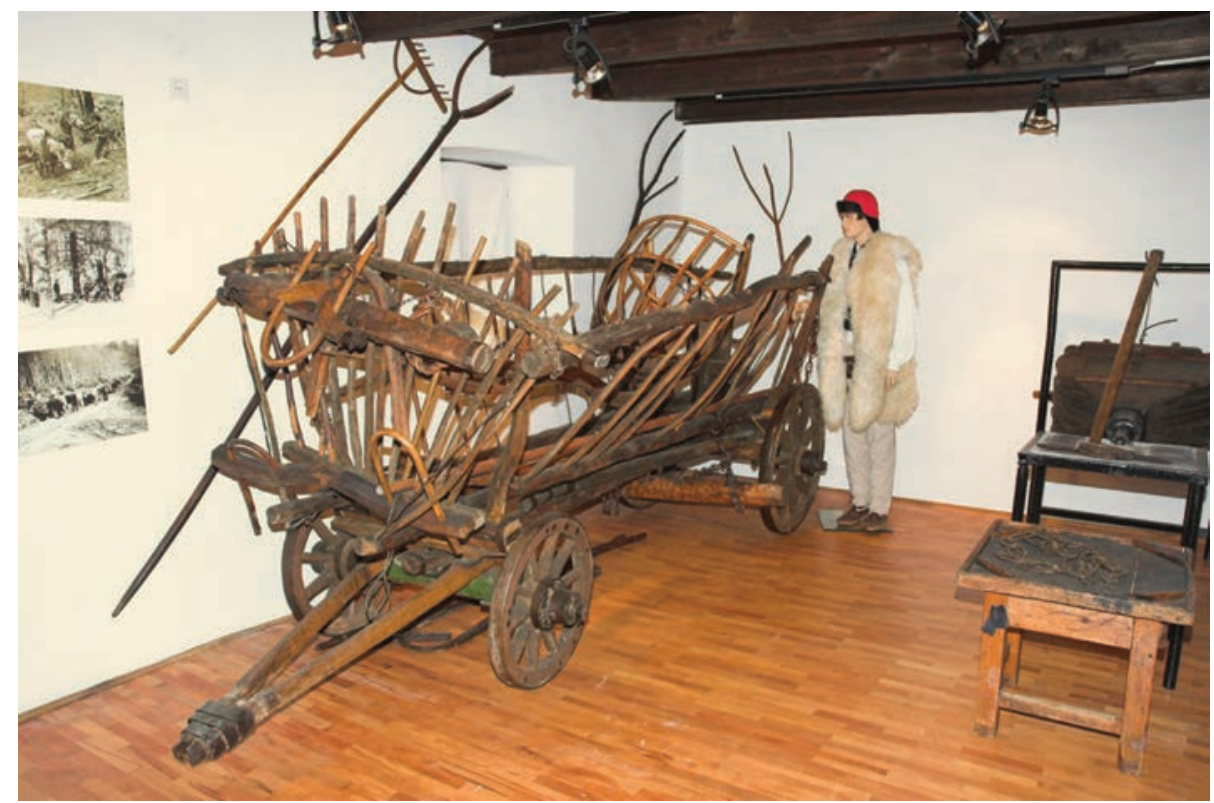

Slika 3: Zaprę̌na kola, mladić Bunjevac i dio kovačije, GMS; snimio Darko Nekić, svibanj 2006.

Pčelarstvom su se bavili pojedinci i to isključivo za vlastite potrebe (jednog domaćinstva). Kirijanje je bila dopunska djelatnost koja se prenosila generacijama i to po muškoj lozi. Dodatni izvor prihoda bila je veoma često trgovina ogrijevnim drvetom i prodaja mlijeka i ostalih proizvoda u Grad Senj. Na području Krivoga Puta pojedinci su vješto proizvodili predmete i alate koji bi se koristili za: sječu drva, obradu zemlje, košnju i sakupljanje sijena, izvlačenje drvene građe iz šume i njegovu obradu, odnosno za izradu svih vrsta alata i proizvoda od drveta, primjerice - bačvarskog alata, te glazbenih instrumenata, od drveta i kože.

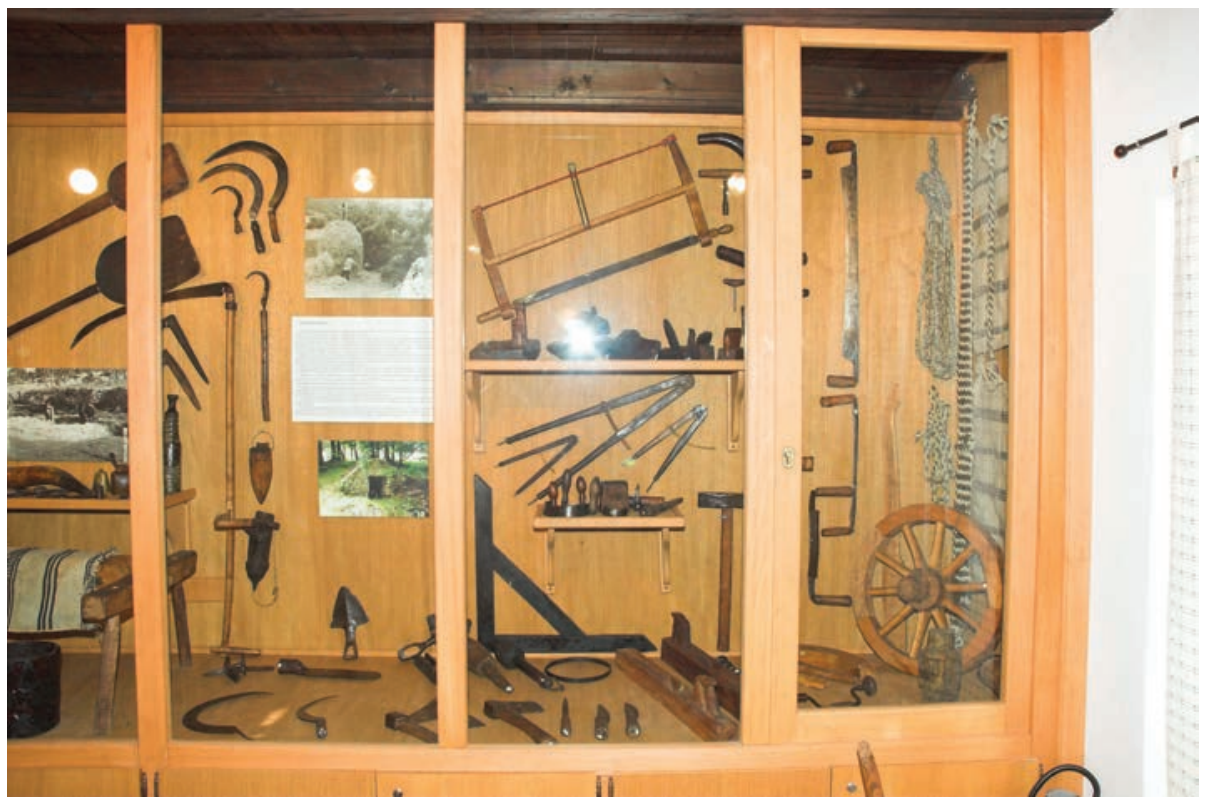

Slika 4: Poljodjelski i ostali alati, GMS; snimio Darko Nekić, svibanj 2006.

Budući da sve ove gospodarske grane ipak nisu bile dostatne za život, muškarci su od druge polovice 19. stoljeća pronalazili dodatne izvore prihoda. Najčešće bi to bio (privremeni ili trajni) odlazak na rad u Slavoniju, Bosnu, zapadnu Europu ili prekomorske zemlje (SAD i Kanada). ${ }^{20}$

20 Više o migracijama s područja Krivoga Puta vidi u prilozima Marijete Rajković, u prvom svesku Monografije, str. $79-122$. 


\subsection{KOVAČ I KOVAČIJA}

$\mathrm{D}$ o sedamdesetih godina 20. stoljeća Bunjevci s područja Krivoga Puta, te Krasna i okolice, intenzivno su koristili usluge kovača u kovačijama. Obzirom da je do sedamdesetih godina 20. stoljeća gotovo svaka kuća imala konja ili vola, odnosno da je poljoprivredni alat činio neophodan dio kućnog inventara, te da se kovačkim poslom bavio vrlo mali broj ljudi, kovački posao u kovačiji odvijao se tijekom cijeloga dana: potkivanje konja i volova, izrada kovanih dijelova za drvena kola i dijelova alata, popravljanje sjekira, motika, krampova i plugova.

Te je kovače lokalna zajednica nazivala profesionalnim kovačima, a ta se odrednica temeljila najčešće na kvaliteti njihovih vještina i na kriteriju nasljeđivanja (pozitivnije su se vrednovali oni koji su nasljeđivali taj zanat unutar obitelji). Oni kazivači koji su bili samouki, odnosno, sami su, bez poduke starijih, zanat usavršili uz drugi posao (primjerice izvlačenje trupaca iz šume, kirijanje) i počeli u manjoj mjeri kovati za vlastite potrebe i po narudžbi mještana, nazivani su priučenima ili poluprofesionalnima. Kovački se posao veoma cijenio zbog fizičke mukotrpnosti.

Sedamdesetih godina 20. stoljeća postupno dolazi do prestanka korištenja kola, konja i volova zbog pojave motornih vozila i tvorničke proizvodnje. Tada postupno prestaje potreba za uslugama kovačije jer nestaje potrebe za ručno kovanim proizvodima.

Zbirka sadržava kako predmete kovačke proizvodnje, tako i one koje su kovači koristili pri proizvodnji alata, dijelova konjske opreme, dijelova za drvena kola.

\subsection{TRADICIJSKI PRIJEVOZ 22}

$\mathrm{K}$ od Bunjevaca u senjskoj okolici, a osobito onih nastanjenih u Podgorju, bile su izražene sezonske seobe. Zimi su boravili u nižim i toplijim predjelima, a proljepšanjem vremena i kopnjenjem snijega postupno su sa stokom selili u više predjele gdje su boravili ljeti.

U najranijim razdobljima, kada nije bilo izgrađenih putova i cesta, najkorištenije životinje za transport bile su magarci i mule. Za potrebe transporta izrađivali su se samari. Ispod drvenog dijela samara stavljala se stelja - platno od konoplje koje se gusto tkalo i unutar kojeg se stavljala slama od zobi kako bi se zaštitila leđa magarca.

Izgradnjom putova do važnijih naselja u širu uporabu ulaze zaprežna kola koja najčešće vuku konji i volovi i koja su u uporabi ostala sve do današnjih dana.

Zbirka sadržava samar, kožnu opremu za gonjenje i sl.

\subsection{OPSKRBA ROBOM ${ }^{23}$}

$\mathrm{P}$ itka voda i danas je problem stanovnika planinskih sela u senjskoj okolici koja su naseljena Bunjevcima. Nedostatak pitke vode bio je jedan od važnijih razloga iseljavanja. Kako je velika udaljenost od izvora pitkom vodom otežavala život i rad, Bunjevci su kroz povijest koristili prirodne osobitosti terena i izrađivali vodoopskrbne sustave. Kao najpoznatiji prirodni vodoopskrbni sustav u planinskim dijelovima, korištene su snježnice (snižnice). U nižim predjelima za prikupljanje vode korištene su prirodne udubine u stijenama u kojima se prikupljala kišnica i koje su ponekad bile povezane u cijele vodoopskrbne sustave.

Od druge polovice 19. stoljeća na području Krivoga Puta počinju se graditi šterne (cisterne) najprije u tehnici suhozida s nepropusnim slojem od gline (ilovače), a kasnije uporabom modernih građevinskih materijala. Kako je gradnja šterni bila iznimno zahtjevna i skupa, te tako nedostupna većem dijelu stanovništva, građene su i tzv. državne šterne, po jedna ili najviše dvije, za svako naselje.

${ }_{21}$ Tekst za legendu koja se odnosi na dio zbirke o kovačima, napisala je Tihana Rubić.

22 Tekst za legendu koja se odnosi na tradicijski prijevoz, napisala je Danijela Birt.

23 Tekst za legendu koja se odnosi na opskrbu vodom, napisala je Danijela Birt. 
Za transport i korištenje vode postojalo je nekoliko vrsta drvenih posuda: bačve, barilci, burila (burla) $i$ žbanjice. Svi ti predmeti izloženi su u nekoliko primjeraka.

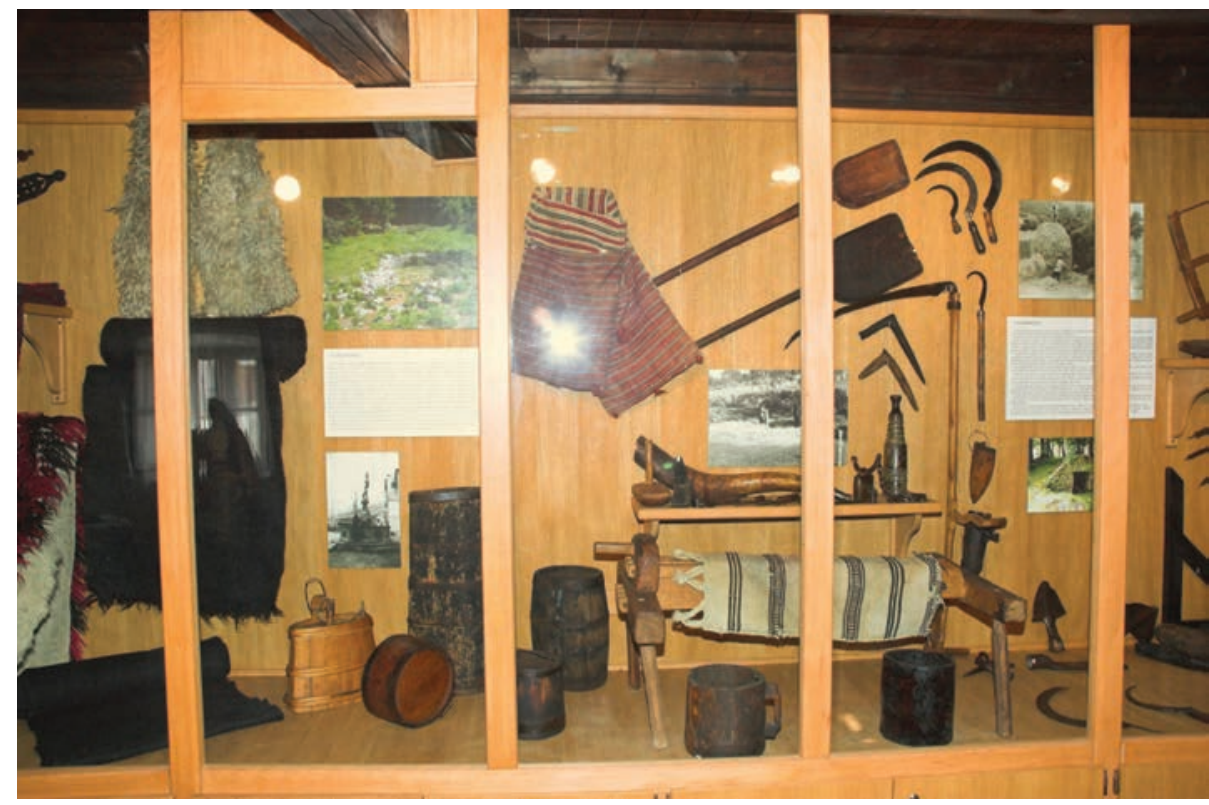

Slika 5: Detalj į̌ložbe s prikazom inventara za vodoopskerbu, GMS; snimio Darko Nekić, svibanj 2006.

\subsection{ODIJEVANJE I TEKSTILNO RUKOTVORSTVO}

Teć početkom 20. stoljeća tradicijsko ruho, odnosno predmeti ručne proizvodnje, počinju nestajati iz senjske okolice, tako da ih i najstariji stanovnici jako slabo pamte.

Ženska odjeća podijeljena je na donju (košulja i podsuknja) i gornju (haljine za koje postoji nekoliko naziva (flajda, alja, kiklja)). Preko haljina nosila se pregača (zaslon). Zimi žene nisu nosile kapute, nego pletene maje koje najčešće nisu bile ukrašene.

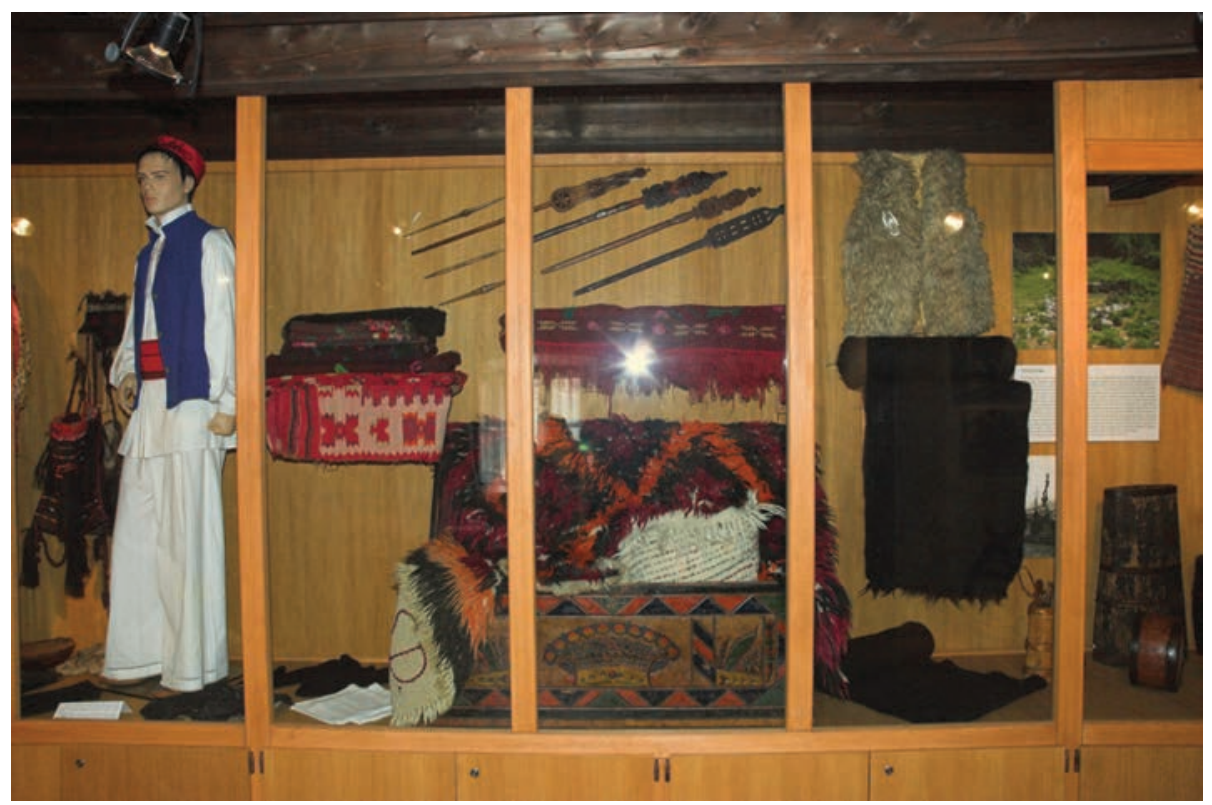

Slika 6: Detalj izložbe s prikazom tekstilnih predmeta, GMS; snimio Darko Nekić, svibanj 2006. 
U mušku donju odjeću spadale su gaće, a u gornju: košulja, hlače, prsluk, džemper, čarape i natikače. Zimi se nosio kratki kaput dužine do bokova tzv. ćurak, a pojedini odjevni predmeti bili su izrađeni i od kože (kožun i šubara).

Glavna sirovina za izradu odjevnih predmeta bila je vuna. Poslije pranja i dijeljenja vuna se čupala rukama i vlačila na gargašse (češljeve), što se obično radilo na prelima. Tako obrađena vuna motala se u kudilju (smotuljak), zatim prela i motala u klupka. U ranijim razdobljima vuna se bojala (strojila, mastila) prirodnim bojama dobivenim od orahova lišća i kore, duhana, jasenove kore, rušvice (grmolike biljke), dok se u novijim razdobljima za bojanje upotrebljavala industrijska boja nabavljana u Senju.

Osim vune, za proizvodnju odjevnih predmeta koristili su se lan i konoplja od kojih su izrađivane ženske donje košulje, muške donje gaće, plahte, posteljina i ručnici i koža za izradu kožuna i šubara. Od kože izrađivala se i obuća, posebno opanci.

Da bismo što bolje dočarali način odijevanja, za potrebe izložbe izradili smo replike četiriju nošnji i to: svečanu i radnu nošnju djevojke Bunjevke, te svečanu i radnu nošnju mladića Bunjevca.

\section{TRADICIJSKA PREHRANA ${ }^{24}$}

Svakodnevna prehrana ruralnog stanovništva ovisila je o načinu privređivanja. Budući da su se Bunjevci u senjskoj okolici uglavnom bavili stočarstvom prehrana im je bila bazirana na mlijeku i mliječnim proizvodima: kiselom mlijeku - kiselini, siru i putru. Kiselina se najčešće jela s palentom, te samostalno. Jedan od najpoznatijih bunjevačkih sireva je sir škripavac čiji je naziv povezan uz karakterističan zvuk (škripanje) prilikom konzumacije.

Nezamjenjiva namirnica bio je krumpir. Osim krumpira, često se koristio i kupus (zelje), koji se sadio na vlastitoj zemlji ili nabavljao u Lici. Zelje se kiselilo i pripremalo u kombinaciji s mesom.

Najraširenije žitarice bile su ječam i pšenica od kojih se dobivalo brašno za pečenje kruha. Kruh se pekao pod pekom, a od šezdesetih godina 20. stoljeća u rolu, odnosno štednjaku. Zbog klimatskih obilježja i nedostatka plodne zemlje sadilo se malo voća, uglavnom su to bile jabuke. Često se sakupljalo samoniklo bilje i šumski plodovi (drinjule, jagode, maline, merale, šipak i crne jagode, trnjule).

Prehrana ribom i morskim proizvodima nije bila zastupljena kod primorskih Bunjevaca iako je veliki dio njih živio u blizini mora. Tek u novije vrijeme dobivaju veći značaj u prehrani.

Za piće se koristila voda, dok se vino nabavljalo samo za svadbe i ljetne košnje. U primorju su Bunjevci pekli rakiju od šmrike tzv. šmrikovaču, a od šumskih plodova izrađivali su slatka pića među kojima su najpoznatiji malinovac i trambuva.

Zbirka sadržava primjere posuđenog samoniklog bilja kao i posude za njihovu pripravu.

\section{UNUTRAŠNJOST KUĆE ${ }^{25}$}

Stambene kuće i ljetne stanove Krivopućana možemo podijeliti u tri kategorije: kuće s odvojenim štala-

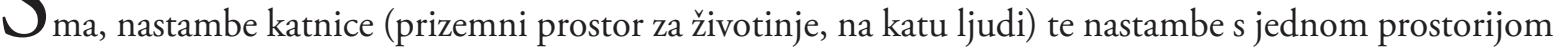
- pojate. Ove posljednje predstavljaju najjednostavniji oblik, a sastojale su se od jedne prostorije, pregrađene na dva dijela pomoću drvenih daščica ili kamena. U jednom dijelu boravili su ljudi, a u drugom blago: Ulazile bi krave i ljudi na ista vrata, tu je bilo ognjište i visile su police sa sudem. U ovu su prostoriju mogla stati dva kreveta ili se umjesto njih koristila sečija sabita od dasaka - nekoliko dasaka postavilo bi se na male nožice, te se na to stavilo malo slame (u strožu ili tekstilnih predmeta), zatim drvena klupica i nekoliko stoličica, kaštrola (kotao) u kojem se palenta kuvala, lonac i nekoliko padelica (manje zdjelice).

${ }_{24}$ Tekst za legendu koja se odnosi na tradicijsku prehranu, napisala je Jasmina Jurković.

25 Tekst za legendu koja se odnosi na tradicijsko graditeljstvo (unutrašnjost kuće), napisale su Ivana Šarić Žic i Marijeta Rajković. 


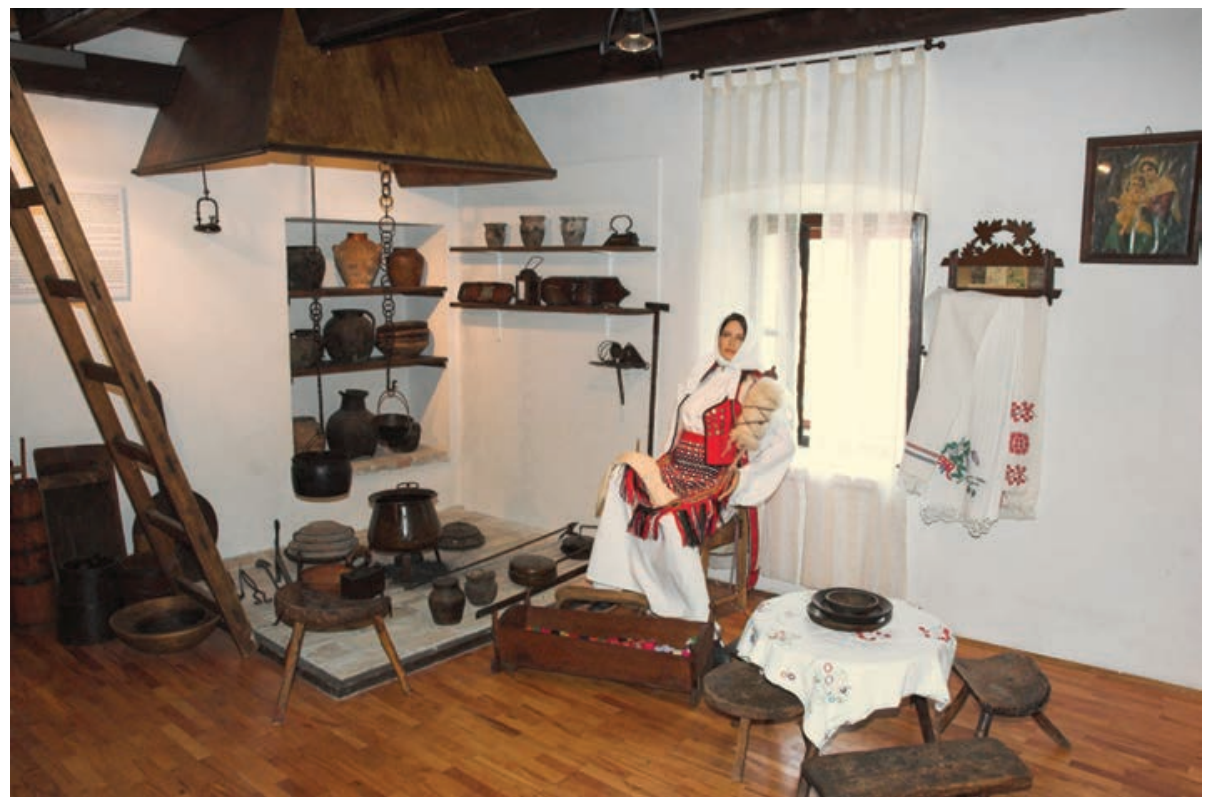

Slika 7: Unutrašnjost bunjevačke kuće, GMS; snimio Darko Nekić, svibanj 2006.

Najrašireniji oblik i kuća i ljetnih stanova bile su nastambe u kojima su u prizemlju boravile životinje, a na katu ljudi. Donji, prizemni dio nazivao se štala, a gornji dio kuća. Gornji dio bijelio se vapnom do pola. U kućama su se nalazila otvorena ognjišta, koja su se počela zamjenjivati pećima - kozama, a za vrijeme Drugoga svjetskog rata na ognjištima su kuhali za svinje. U pojedinim obiteljima takve se prostorije danas koriste za dimljenje i sušenje mesa. Pokraj ognjišta su bile tronoge, na kojima se kuhalo jelo u padeli ili mliko, a u kaštroli se kuhala palenta, krumpir i jušna jela. Kruh, meso i krumpir pekli su se pod pekama. $\mathrm{U}$ istoj prostoriji bio je i mali ili veliki stol. Oko malog stola - stolice ljudi su sjedili na tronošcima, a oko velikog (koji se počeo upotrebljavati iza Drugoga svjetskog rata) na stolicama. Polica za sude pričvršćivala se na zid. Od posuđa koristilo se: velike zdile za donit na stol svoj familiji, cinjani pinjati (aluminijski tanjuri), paljak (za grabiti juhu) te razni glineni čupovi.

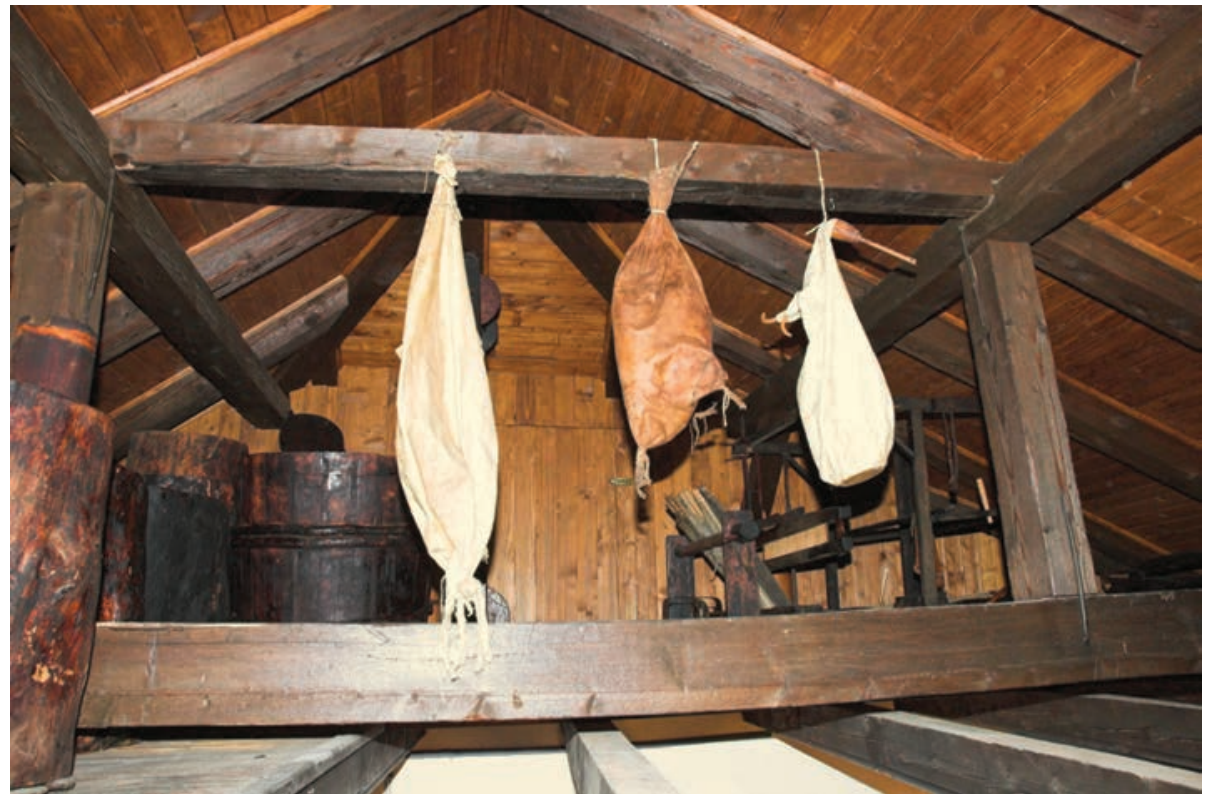

Slika 8: Unutrašjost bunjevačke kuće sa tavanskim prostorom, GMS; snimio Darko Nekić, svibanj 2006. 
Kreveti su rađeni od punog drveta i razdvojeni su svaki za sebe. Umjesto dekama, pokrivalo se ličkim vunenim biljcima. Spavalo se $i$ u podu gdje je seno bilo. Tekstilne predmete držali su u škrinjama, u borovima s trima ladicama ili u ormarima.

Budući da je struja uvedena tek sedamdesetih godina 20. stoljeća, za rasvjetu su korištene svijeće od voska i petrolejke.

Spomenuti su se oblici stanovanja i uređenja unutrašnjosti kuće, zadržali mahom do Drugoga svjetskog rata, a kasnije su postupno bili napušteni. U socijalističkom razdoblju, kuće su dograđivane horizontalno, a ponekad je bio nadograđen katni dio.

Sav dio ranijeg inventara, koji se u tekstu spominje, izložen je u Zbirci i postavljen u vidu prikaza funkcioniranja dijelova unutrašnjosti kuće (ognjište s inventarom, potkrovlje kuće s inventarom i sl.).

Smatramo da je koncepcijom ove izložbe materijalna i duhovna kultura primorskih Bunjevaca zanimljivo prezentirana javnosti. U inventarizaciji, a dijelom i u idejnoj koncepciji Zbirke, sudjelovale su etnologinje Milana Černelić, Marijeta Rajkovićc ${ }^{26}$, Tihana Rubić ${ }^{27}$, Danijela Birt ${ }^{28}$ i Ivana Šaric $\check{Z}_{i c}{ }^{29}$, ali najveći su dio organizacije i realizacije poslova, te idejnog rješenja Zbirke, ponijeli djelatnici Gradskog muzeja Senj: Blaženka Ljubović, Darko Nekić i Melanija Prpić; te Studio Gobbo d.o.o. iz Grožnjana.

Inventarizacija je rađena tako da je redom popisan svaki predmet koji smo zatekli u Zbirci, izuzev onih koji su bili u nepopravljivo lošem stanju, bez mogućnosti restauracije (primjerice, od moljaca većim dijelom uništena vunena torba ili dijelovi tronošca koji su bili u izrazito trusnome stanju uslijed crvotočine i sl.). Izvršena je inventarizacija cjelokupnog preostalog fundusa Zbirke, odnosno, svakom je predmetu pridružen broj s odgovarajućom inventarnom karticom u koju su upisivani sljedeći podaci o predmetu: naziv predmeta (lokalni, stručni), materijal i tehnika izrade, opis i stanje predmeta, ime onog/one koji/a je predmet izradio/la, dimenzije predmeta, broj komada, mjesto izvedbe i uporabe, način na koji je predmet dospio u Muzej, nabavnu cijenu i bilješku (napomenu) osobe koja je predmet inventirala. Svaki je predmet fotografski dokumentiran te je fotografija naknadno pridružena pripadajućoj inventarnoj kartici.

Vrijedno je opisati specifičnu situaciju koju smo zatekli u početku inventarizacije: već je spomenuto kako je prof. A. Glavičić prethodno bio inventirao određen broj predmeta i dosljedno ih upisivao u inventarnu knjigu. Predmeti su opisani i pridružen im je pripadajući broj. Nerijetko je te predmete i donosio sam A. Glavičić ili bi ih on kao stručna osoba preuzimao za Muzej i odmah po primitku upisivao i opisivao. Dogodilo se ipak da su se u međuvremenu, uslijed trošnosti, papirići s pripadajućim brojem odlijepili s predmeta. Na osnovu spomenute inventarne knjige pokušalo se prema opisima koji se u Knjizi nalaze odgonetnuti o kojem se predmetu radi, jer je pored opisa predmeta knjiga sadržavala i iznimno vrijedne podatke o primitku predmeta, osobi koja je predmet koristila i/ili darovala, otkupnu cijenu i sl. Međutim, opisi predmeta su bili vrlo uopćeni, odnosno, nisu sadržavali nekakve odrednice koje bi pri prepoznavanju predmeta bile jasan označitelj konkretnog predmeta. Trebalo je stoga započeti s novom inventarizacijom predmeta te svakom predmetu pridružiti novi inventarni broj.

Analizom postojećih predmeta unutar Zbirke, ustvrdilo se i na koji ćemo način tematski organizirati novi postav; tematske cjeline koje smo predstavili u novom postavu uglavnom su one za koje smo raspolagali najvećim brojem predmeta, te najočuvanijim i najraznovrsnijim predmetima, onima koji mogu

26 Tada diplomirana etnologinja, a danas znanstvena novakinja u zvanju asistentice, na Odsjeku za etnologiju i kulturnu antropologiju Filozofskog fakulteta Sveučilišta u Zagrebu.

27 Tada diplomirana etnologinja, a danas znanstvena novakinja u zvanju asistentice, na Odsjeku za etnologiju i kulturnu antropologiju Filozofskog fakulteta Sveučilišta u Zagrebu.

28 Tada studentica etnologije, a danas znanstvena novakinja u zvanju asistentice, na Odsjeku za etnologiju i kulturnu antropologiju Sveučilišta u Zadru.

29 Tada djelatnica Ministarstva kulture RH, Konzervatorskog odjela u Rijeci, a danas kustosica Pomorskog i povijesnog muzeja Hrvatskog primorja u Rijeci. 
cjelovitije „ispričati priču“ o nekoj tematskoj cjelini unutar postava koju želimo prikazati (primjerice, otvoreno ognjište s priborom; kovačija).

Svi izlošci unutar novog postava slikovito svjedoče o ručnoj proizvodnji kao isključivo zastupljenoj na ovomu području do otprilike prvih godina nakon Drugoga svjetskog rata, te o skromnosti i oskudnosti u načinu življenja i privređivanja.

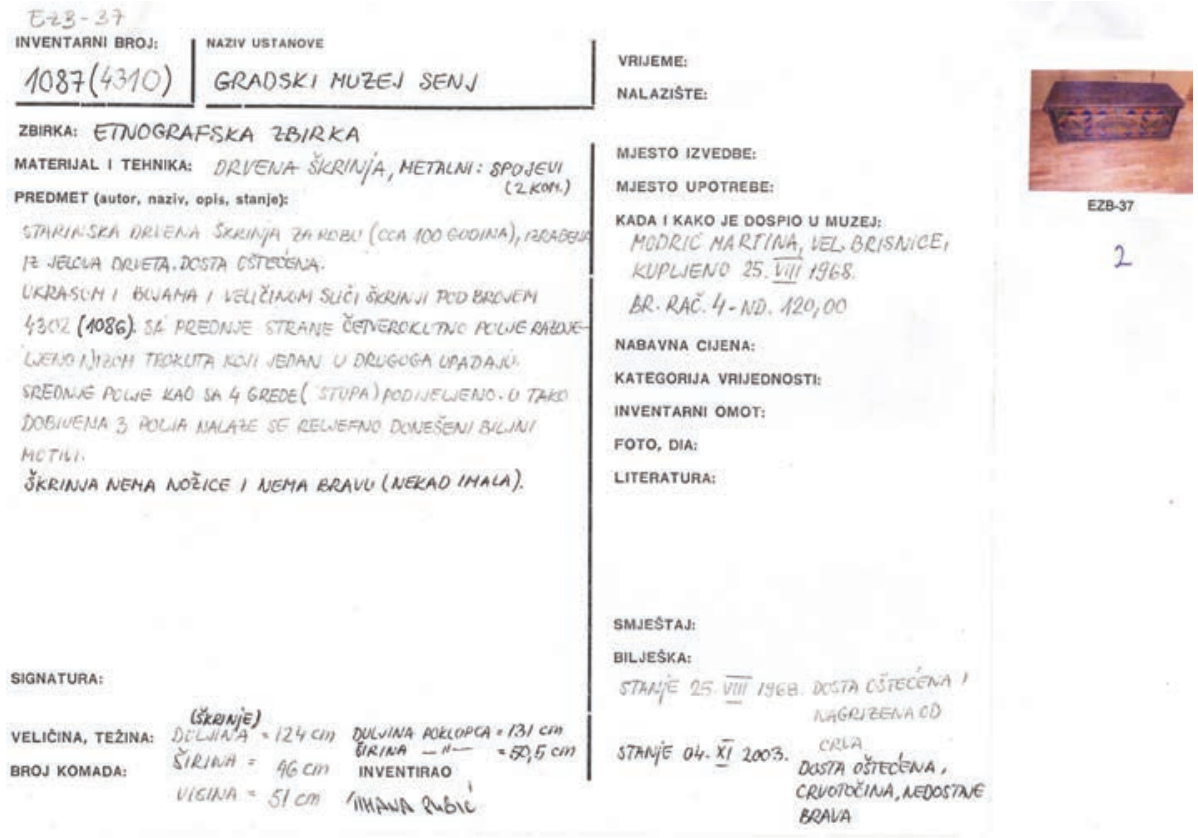

Slika 9: Primjer ispunjene inventarne kartice koja je pisana prilikom nove inventarizacije Etnografske zbirke.

\section{GOSTOVANJE ZBIRKE/ IZLOŽBE U SUBOTICI}

7 birka birka, kao dio stalnog postava Muzeja, danas obogaćuje muzejsku i turističku ponudu Grada. ${ }^{30}$ Gradski muzej Senj i Etnografsku zbirku godišnje posjeti oko 6000 posjetitelja, od čega većinu čine školska djeca koja u programu imaju terensku nastavu. Ova im zbirka tako nadopunjuje i obogaćuje osnovnoškolski i srednjoškolski nastavni program, ali i njihove spoznaje o životu u ruralnoj sredini tijekom 20. stoljeća.

Pored toga, gostovanjem Izložbe, kulturna se baština Bunjevaca pokazala kao moguća kulturna poveznica među raseljenim bunjevačkim grupama. To je potvrđeno prigodom otvaranja stalnog postava u Gradskom muzeju Senj. ${ }^{31}$ Svi su oni putem pisanih i vizualnih medija doznali kako su u Muzeju u tijeku pripreme za otvaranje Etnografske zbirke o tradicijskoj kulturi primorskih Bunjevaca. Obratili su se djelatnicima Muzeja s molbom i željom da ta izložba bude predstavljena i bačkim Hrvatima Bunjevcima u Gradskom muzeju u Subotici.

Naglasili su kako je hrvatski (bunjevački) identitet živ u svijesti i uporabi vojvođanskog stanovništva, te kako su uvjereni da bi gostovanje Izložbe pobudilo veliki interes kod mnogih tamošnjih Bunjavaca te dalo potporu očuvanju hrvatske narodne svijesti i identiteta među bačkim Hrvatima Bunjevcima.

30 Na otvorenju su bili prisutni predstavnici Demokratskog saveza Hrvata Vojvodine iz Subotice, gospodin Petar Kuntić, dipl.ing., predsjednik ove stranke i zamjenik predsjednika općine Subotica i dr. sc. Slaven Bačić, glavni urednik Leksikona podunavskih Hrvata - Bunjevaca i Šokaca.

31 O svom boravku u Senju na otvaranju izložbe - zbirke stalnog postava u Gradskom muzeju u Senju 20. travnja 2006. godine, navedena gospoda dala su intervjue u glasilima Hrvatska riječ, 28. travanj 2006. i Glasu ravnice, travanj 2006. u kojima su naglasili da je ovom zbirkom otvoren put suradnje unutar dviju bunjevačkih skupina i kako očekuju gostovanje Zbirke-Izložbe u Gradskom muzeju u Subotici. 
Ubrzo se u organizaciju izložbe u Subotici uključio Gradski muzej Subotice i Generalni konzulat $\mathrm{RH}$ u Subotici, na čelu s generalnim konzulom mr. sc. Davorom Vidišom koji je s projektom upoznao brojne institucije RH, kao npr. Upravu za kulturni razvitak i kulturnu politiku Ministarstva kulture RH, Upravu za međunarodnu kulturnu suradnju Ministarstva kulture RH, Samostalni odjel za kulturu Ministarstva vanjskih poslova i europskih integracija $\mathrm{RH}$.

Nije prošlo puno vremena od ideje do realizacije. Izložba je prenesena u cijelosti i prilagođena za tu priliku raspoloživom muzejskom prostoru. Otvorena je 20. srpnja 2007. godine, pod nazivom Bunjevci na senjskom području. ${ }^{32}$

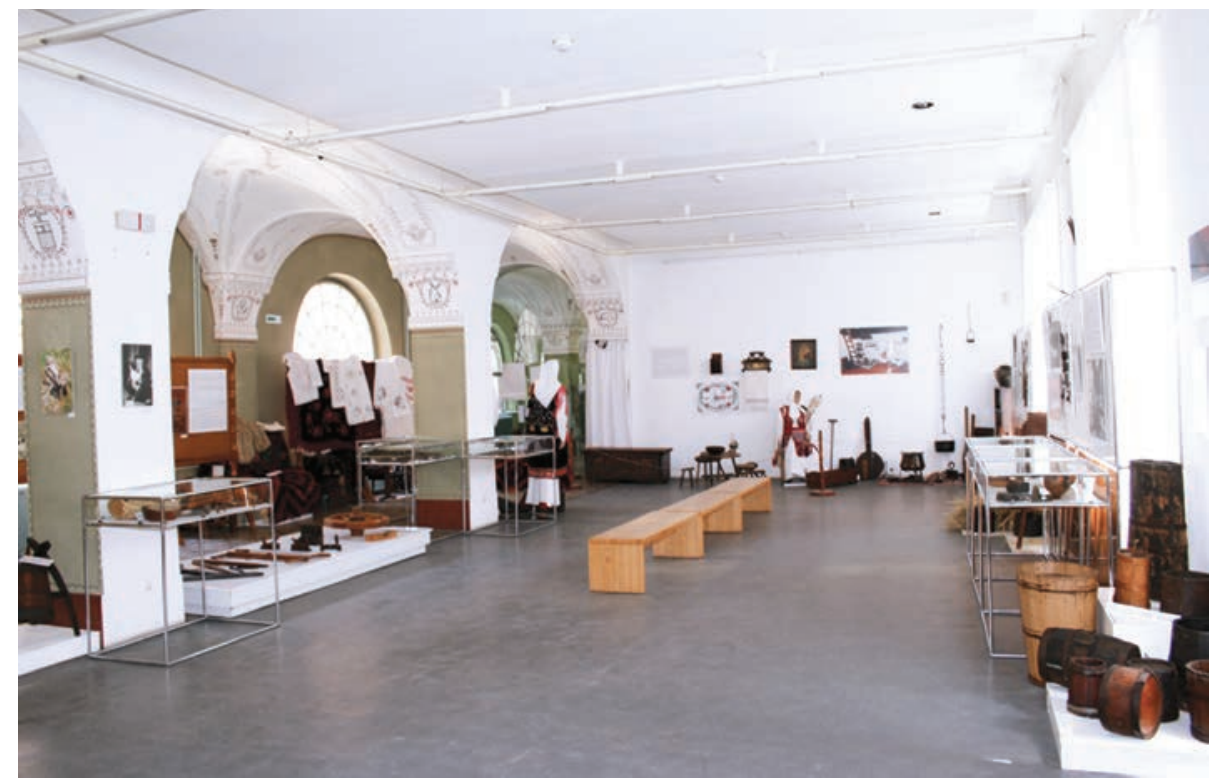

Slika 10: Prikaz ižložbe Bunjevci na senjskom području, postavljene u Gradskom muzeju Subotice; snimila Melanija Prpić, srpanj 2007.

U ime organizatora izložbe Gradskog muzeja Senj skupu se obratila ravnateljica Gradskog muzeja Senj prof. Blaženka Ljubović. ${ }^{33}$ Skupu su se obratili i prof. Istvan Hullo, ravnatelj Gradskog muzeja Subotice, koji je naglasio osobno zadovoljstvo time što je imao mogućnost ugostiti Izložbu, čime se povezuju dva muzeja i dvije grane Bunjevaca, s nadom da će se suradnja nastaviti i na nekim budućim projektima. Skup je pozdravio i Petar Kuntić dipl.ing., zamjenik predsjednika Općine Subotica. On je bio zadovoljan time što je uspio ostvariti projekt čiji je bio inicijator i ovom izložbom zbližiti dvije grane Bunjevaca zajedničkih korijena. Nazočan je bio i mr.sc. Davor Vidiš, generalni konzul RH, koji je rekao kako ideja ove izložbe nije da riješi prijepore koji su prisutni po pitanju Bunjevaca, ali je moguće da će ona doprinijeti boljem razumijevanju identiteta Bunjevaca. Prisutnima se obratio i prof. Darko Nekić, gradonačelnik

32 Uz svesrednu pomoć domaćina predvođenih tajnikom Gradskog muzeja Subotice Svetislavom Milankovićem, dipl. iur., izložbu su postavili: djelatnici Gradskog muzeja Senj (ravnateljica, viši kustos Blaženka Ljubović, prof. i tajnica Melanija Prpić, dipl.oec.), uz stručnu pomoć Marijete Rajković, prof., s Odsjeka za etnologiju i kulturnu antropologiju Filozofskog fakulteta Sveučilišta u Zagrebu.

33 U svom pozdravnom govoru prof. B. Ljubović je naglasila: „Sretni smo što je ovaj projekt uspio uz financijsku pomoć i podršku više institucija: Ministarstva kulture RH, Diplomatsko konzularnog predstavnišstva u Subotici, Grada Senja, naših dvaju muzeja domaćina Gradskog muzeja Subotice i Gradskog muzeja Senj i stručnu pomoć djelatnika Odsjeka za etnologiju i kulturnu antropologiju Filozofskog fakulteta u Zagrebu. Svim ovim institucijama, ovom prigodom srdačno zahvaljujemo na pruženoj stručnoj i financijskoj pomoći.

Ovo kulturno događanje predstavljanja materijalne kulture Bunjevaca sa senjskog područja sve nas je zajedno usrećilo. Smatramo ga vrlo značajnim za muzeje u Subotici i Senju, ali i za naše Bunjevce čiji duh, kroz njihovu kulturnu baštinu, struji među nama, obogaćuje nas, oplemenjuje ali i upozorava na važnost očuvanja te baštine za buduće generacije u ovome danas globaliziranom svijetu koji ponekad ima negativne posljedice za identitet pojedinca i društva uopće." 
Grada Senja i donedavni kustos Muzeja, istaknuvši kako je i sam u ime Grada, kao osnivača Gradskog muzeja Senj, podržao ovaj projekt u cilju kulturnog zbližavanja dviju bunjevačkih grana. Kao muzelac i sam je dao doprinos u formiranju novog postava Zbirke. Grgo Kujundžić, predsjednik kulturnog događanja Dužijance bunjevačkih Hrvata u Subotici, obratio se okupljenima izrazivši nadu da će u budućnosti izložba o Dužijanci iz Subotice otići za Senj (Hrvatska riječ 231 2007:30-31; Subotičke 56 2007:8-9). $\mathrm{Na}$ kraju se okupljenim obratio i mons. dr. Mile Bogović, biskup gospićko-senjski, koji je govor započeo rekavši kako je bunjevački biskup. ${ }^{34}$

Izložba je u Subotici bila otvorena do 20. kolovoza 2007. godine. ${ }^{35}$

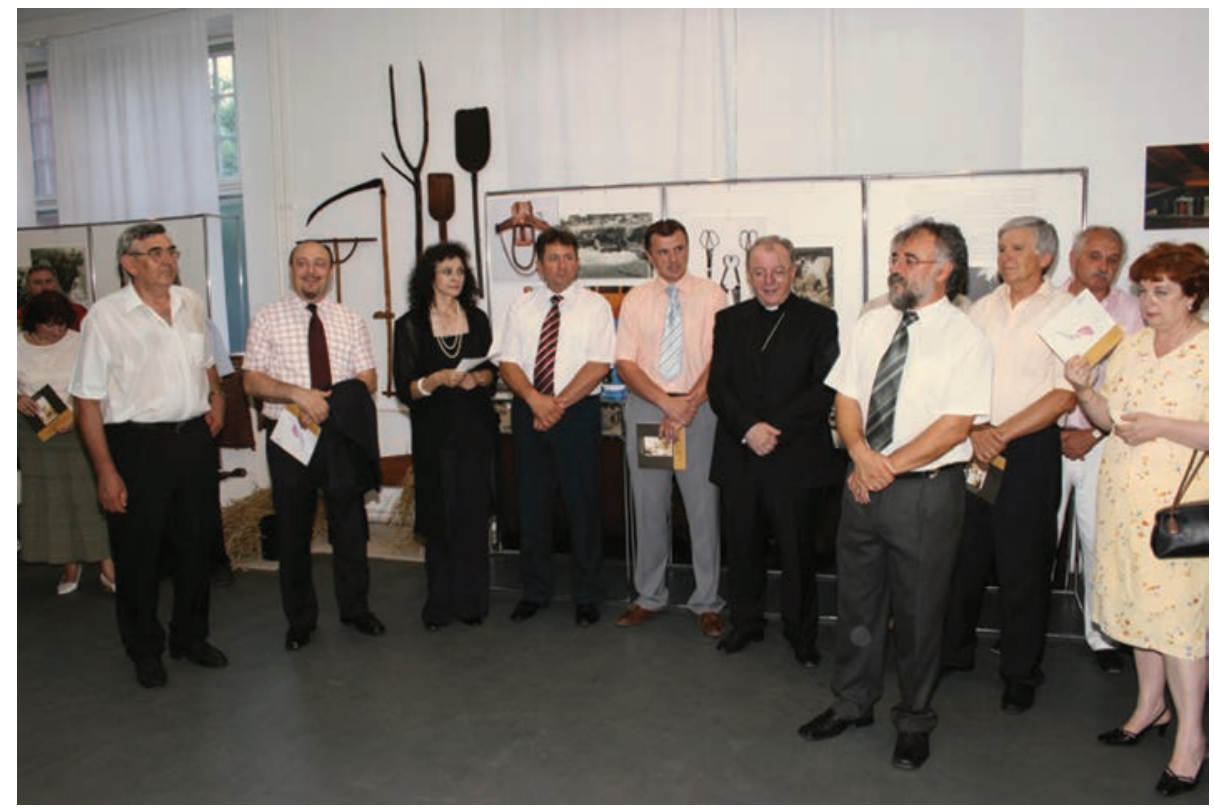

Slika 11: Otvorenja i₹̌ložbe u Gradskom muzeju u Subotici; snimila Melanija Prpić, srpanj 2007.

34 U svom je govoru naglasio kako je po drugi put među njima, da su ga lijepo primili prvi put i da je stoga ponovno došao. Nadalje je naglasio: „Dragi Bunjevci na 'sjeveru Bačke’ nosimo Vam pozdrave iz zapadne Hrvatske. Došli su k vama u pohode predstavnici vlasti, kulture i Crkve s hrvatskog prostora naseljenog pretežno Bunjevcima. Ja sam biskup Bunjevaca koji su se smjestili oko Velebita, 'kršne gore naše', pa se može reći da sam bunjevački biskup. Bunjevci su se selili na sve strane pa su se ovako i razgranali. Drago nam je da se bar povremeno uspostavljaju među njima veze. Ovaj susret omogućili su Grad Senj i njegov Gradski muzej. Nije ni čudo kada znamo da su danas čelni ljudi Grada i Muzeja Bunjevci. Što te veze budu čvrršce, to će preko njih Bunjevci bolje prepoznavati svoje zajedničko deblo iz kojega su potekli i koje i danas donosi slične plodove. Ova izložba je već jedan lijep način takva prepoznavanja i izmjene kulturnog bogatstva. Bunjevci oko Velebita: iz Primorja i Like žele doprinijeti da se ojačaju veze ne samo između dviju bunjevačkih grana nego također da se veze Bunjevaca 'sa sjevera Bačke’ još čvršće povežu i s matičnim hrvatskim korpusom."

35 Ovo kulturno događanje popratili su brojni mediji: Televizija Novi Sad, Radio Subotica (program za Hrvate) i glasila koja inače prate događanja vezana za bunjevačke Hrvate u Subotici: Hrvatska riječ, Glas ravnice, Subotičke. Uz izložbu je tiskan prigodni deplijan čiji su tekstovi prevedeni na mađarski i srpski jezik.Prema riječima tajnika Gradskog muzeja Subotice, dipl.iur. Svetislava Milankovića, za nju je pokazan veliki interes te ju je posjetilo preko tisuću posjetitelja. To je dosad najposjećenija izložba u ovom muzeju. O njezinu značenju i važnosti govore i vrlo lijepi utisci posjetitelja zabilježeni u Knjizi utisaka Gradskog muzeja Subotice, kako navodi gdin. Milanković. 


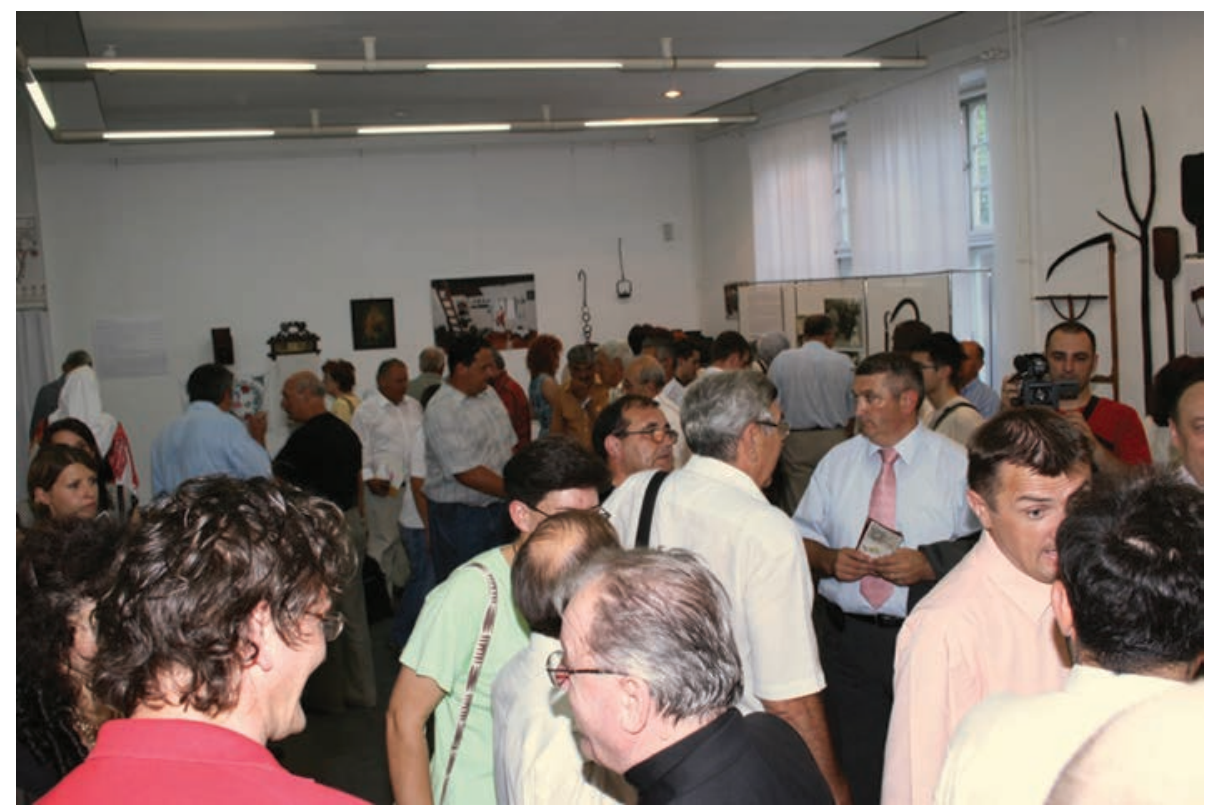

Slika 12: Posjetitelji na otvorenju izložbe u Gradskom muгeju u Subotici; snimila Melanija Prpic, srpanj 2007.

\section{ZAKLJUČNA RAZMATRANJA}

Nova etnografska zbirka, kao dio stalnog postava Gradskog muzeja Senj, danas predstavlja dio opće kulturne ponude Grada Senja koja se aktivno koristi u turističko-kulturne promidžbene svrhe Grada Senja i okolice. Također predstavlja, sustavno i prezentacijski, adekvatniju pohranu vrijednih etnografskih predmeta, te temelj za daljni istraživački i muzeološki rad.

Isto tako, Zbirka nosi i simboličku vrijednost, ponajprije lokalnoj zajednici i stanovnicima Grada Senja.

Nadalje, prepoznaje se i kao mogući okvir za stručnu suradnju, povezivanje, razmjenu iskustava i znanja, promatramo li Muzej na način na koji sugerira autorica ovog priloga, kao dugogodišnja ravnateljica i kustosica Muzeja.

Autorica Zbirku promatra kao mjesto učenja o (vlastitoj) prošlosti, a time i budućnosti, te kao mjesto potvrđivanja bunjevačkog kulturnog identiteta.

\section{LITERATURA I IZVORI:}

Arhiva Gradskog muzeja Senj, 1969; 1970; 1972; 1979.

BOGOVIĆ, Mile (2008.): Župa Krivi Put, u: Živjeti na Krivom Putu. Etnološko-povijesna monografija o primorskim Bunjevcima, 1. svezak, ur. Milana Černelić, Marijeta Rajković, Tihana Rubić, str. 69-75.

ČILAŠ ŠIMPRAGA, Ankica (2008): O krivoputskome govoru, u: Živjeti na Krivom Putu. Etnološkopovijesna monografija o primorskim Bunjevcima, 1. svezak, ur. Milana Černelić, Marijeta Rajković, Tihana Rubić, str. 123-134.

ČERNELIĆ, Milana (2003): Istraživanje tradicijske baštine, identiteta i etnogoneze primorskih Bunjevaca, Senjski zbornik, 30, Senj, 407-424.

ERDELJANOVIĆ, Jovan (1930): O poreklu Bunjevaca, Beograd.

Glas ravnice, br. 103, travanj 2006.

Glas ravnice, br. 110, kolovoz 2007.

Hrvatska riječ, br. 167, 27. travnja 2006, Subotica.

Hrvatska riječ, br. 229 (13. srpanj), 230 (20. srpanj), 231 (27. srpanj), 2007., Subotica. 
KAROLY, Arpad (1890): «Vlasi», koji su iz okolice Bihaćke iselili koncem 16. st, Glasnik Zemaljskog muzeja Sarajevo, III: 243-251, Sarajevo.

PAVELIĆ, Rikard (1991): Stope predaka, Bunjevci u Hrvatskom primorju, Gorskom kotaru i Lici, Rijeka.

PAVIČIĆ, Stjepan (1962): Seobe i naselja u Lici, Zbornik za narodni život i običaje južnih Slavena, Zagreb.

PAVIČIĆ, Stjepan (1966): Raseljenje starosjedilaca i doseljenje Bunjevaca u senjski kraj, Senjski zbornik, 2, 310-378, Senj.

PAVLIČEVIĆ, Dragutin (1989): Seobe Vlaha-Krmpoćana u 17. st., u: Vojne krajine u jugoslavenskim zemljama u novom veku do Karlovačkog mira 1699., 147-172, Beograd.

PAVLIČEVIĆ, Dragutin (1985): Iz prošlosti Krmpota, Klenovica i Ledenica (kratak pregled od početka 20. stoljeća), Vinodolski zbornik, IV, 281-309, Crikvenica.

PAVLIČEVIĆ, Dragutin (1998): O pučanstvu Krbave, Like i Gacke s posebnim osvrtom na Bunjevce, Zbornik Krbavska bitka i njezine posljedice, 203-220, Zagreb.

PETRIĆ, Mario (1966): Prilog proučavanju porijekla Bunjevaca, Glasnik Zemaljskog muzeja Bosne i Hercegovine, 22/21, 87-103, Sarajevo.

SEKULIĆ, Ante (1986): Narodni život i običaji bačkih Bunjevaca, Zbornik za narodni život i običaje Južnih Slavena, knj. 50, 5-474, Zagreb.

Subotičke, br. 56, 2007., Subotica.

ŠARIĆ, Marko (2008): Bunjevci u ranome novom vijeku. Postanak i razvoje jedne predmoderne etnije, u: Živjeti na Krivom Putu. Etnološko-povijesna monografija o primorskim Bunjevcima, 1. svezak, ur. Milana Černelić, Marijeta Rajković, Tihana Rubić, str. 15-43, Zagreb.

Vojvodina, 25. srpnja 2007. 